\title{
THE STIMULATION OF GONAD MATURITY OF ASIAN REDTAIL CATFISH Hemibagrus nemurus (Valenciennes, 1840) THROUGH INDUCTION OF OOCYTE DEVELOPER (Oodev) HORMONE
}

\author{
Devika Kharisma Putri*1, Tarsim, Deny Sapto Chondro Utomo, dan Indra \\ Gumay Yudha ${ }^{2}$
}

\begin{abstract}
Oodev hormone application has been applied to stimulate gonadal maturity so that fish fry could be available outside the spawning season. This research aimed to study the effect of Oodev hormone on the gonadal maturity of asian redtail catfish Hemibagrus nemurus (Valenciennes, 1840). This research method used a completely randomized design (CRD) with 4 doses treatments, i.e 0, 0,25, 0,50, 1,00 $\mathrm{ml} / \mathrm{kg}$. A total of 8 fish were used as replications for each treatment. The parameters measured were the gonado somatic index (GSI) and egg diameter. The results showed that the effect of Oodev hormone on GSI and egg diameter was significantly different $(P<0.05)$. A higher Oodev hormone dose caused an increase of GSI and egg diameter size. The recommended Oodev dose for application is $1 \mathrm{ml} / \mathrm{kg}$.
\end{abstract}

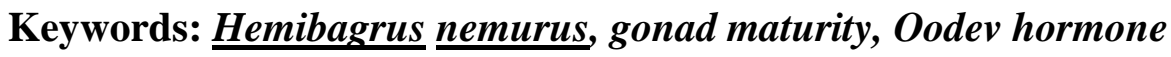

\section{Pendahuluan}

Ikan baung (Hemibagrus nemurus) adalah salah satu spesies ikan air tawar yang memiliki nilai ekonomi penting dan banyak dijumpai di perairan Sumatera, Jawa, dan Kalimantan. Ikan ini sangat digemari untuk dikonsumsi oleh masyarakat sekitar karena memiliki daging yang tebal dan rasa yang lezat. Ikan baung memiliki nilai jual yang tinggi, harga jual ikan baung di pasaran mencapai Rp. 50.000 70.000/kg (Heltonika, 2017).

Permintaan akan ikan baung sangat tinggi dan sudah banyak dibudidaya oleh masyarakat namun hasilnya belum signifikan disebabkan kendala-kendala dalam budidayanya, antara lain ketersediaan benih yang terbatas di luar musim pemijahan. Pemijahan alami ikan baung di alam hanya terjadi sekali dalam setahun (saat musim hujan). Ikan baung jantan matang gonad pada bulan November - Februari, sedangkan ikan baung betina pada bulan Oktober - Januari (Arsjad, 1973 dalam Muflikhah et al., 2005).

Secara alami saat musim pemijahan ikan akan menerima sinyal lingkungan dan diterima oleh saraf pusat yang diteruskan ke otak untuk kemudian otak memberikan perintah ke ptuitari untuk menghasilkan

\footnotetext{
${ }^{1}$ E-mail: devikakharisma@gmail.com

${ }^{2}$ Jurusan Perikanan dan Kelautan, Fakultas Pertanian, Universitas Lampung

Jl. Prof. S. Brodjonegoro No.1 Gedong Meneng Bandar Lampung, 35145
} 
hormon utama yang akan merangsang berbagai macam aktivitas ovari (Berniar et al., 2009). Di luar musim pemijahan sinyal lingkungan yang dibutuhkan tidak tersedia sehingga menyebabkan keterlambatan ketersediaan induk baung yang matang gonad sangat terbatas.

Faktor penyebab lambatnya kematangan gonad ikan baung di luar musim pemijahan adalah berkurangnya kadar (Follicel Stimulating Hormone) FSH dan keberadaan dopamin yang dihasilkan saraf pusat yang dapat menghambat proses (Gonadotropin releasing hormone) GnRH yang menghasilkan (Gonadotropin hormone) $\mathrm{GtH}$ saraf pusat juga menghasilkan dopamin yang dapat menghambat proses sintesis. Untuk itu diperlukan hormon yang dapat meningkatkan FSH dan antidopamin. Upaya yang dapat dilakukan untuk menanggulangi kondisi tersebut, sulitnya mendapatkan indukan ikan baung yang matang gonad di luar musim pemijahan adalah dengan melakukan aplikasi hormonal melalui penyuntikan (Farastuti, 2014).

\section{Bahan dan Metode}

Penelitian ini dilaksanakan pada bulan April - Juli 2018 di Balai Budidaya Ikan Sentral, Purbolinggo, Lampung Timur. Ikan uji yang digunakan adalah induk betina ikan baung dengan bobot rata-rata $\pm 500 \mathrm{~g}$ berjumlah 8 ekor setiap ulangan. Induk yang digunakan sudah memijah dan belum matang gonad.

Perlakuan yang diberikan meliputi A (Larutan fisiologis yaitu $\mathrm{NaCl} 1,0 \mathrm{ml} / \mathrm{kg}$ ), B (Hormon Oodev dengan dosis $0,25 \mathrm{ml} / \mathrm{kg}+\mathrm{NaCl} 0,75$ $\mathrm{ml} / \mathrm{kg}$ ikan (Sihaloho, 2014), C (Hormon Oodev dengan dosis 0,5 $\mathrm{ml} / \mathrm{kg}+$ larutan fisiologis $0,5 \mathrm{ml} / \mathrm{kg}$ ikan (Sihaloho, 2014), dan D (Hormon Oodev dengan dosis 1,0 $\mathrm{ml} / \mathrm{kg}$ ikan (Cholifah, 2016).

Ikan baung dipelihara di kolam permanen yang diberi hapa dengan ukuran $2 \times 1,5 \times 1,5 \mathrm{~m}^{3}$ sebanyak 4 buah dengan ketinggian air $1 \mathrm{~m}$. Pemberian pakan dilakukan sebanyak 2 kali sehari pada pagi dan sore hari sebanyak 3\% dari bobot tubuh ikan baung.

\section{Pengukuran Kualitas Air}

Pengukuran $\mathrm{pH}$ dilakukan selama 1 kali seminggu dan pengukuran suhu dilakukan pada pagi hari (pukul 08.00 WIB) dan sore hari (pukul 17.00 WIB)

\section{Penyuntikan Hormon}

Hormon yang digunakan dalam penelitian ini adalah hormon Oodev. Penyuntikan dilakukan secara intramuscullar pada otot punggung. Penyuntikan dilakukan setiap 2 minggu sekali selama 8 minggu pemeliharaan.

\section{Pengambilan Sampel Gonad}

Pengambilan sampel gonad dilakukan pada minggu ke-0 sebelum dilakukan penyuntikan dan minggu ke-8 setelah penyuntikan. Indukan ditimbang terlebih dahulu dimulai dari lubang anus menuju operkulum secara horizontal. Setelah dibedah, sampel gonad ditimbang kemudian dilakukan proses pengawetan menggunakan larutan formalin $10 \%$ dan disimpan pada botol film dengan suhu ruang untuk dilanjutkan uji histologi. Pengambilan sampel gonad dilakukan 1 ekor/perlakuan pada awal 
pemeliharaan dan 5 ekor/perlakuan pada akhir pemeliharaan.

\section{Parameter Penelitian}

Indeks Kematangan Gonad (IKG)

Nilai IKG dilakukan dengan menghitung persentase perbandingan antara bobot gonad ikan dan bobot tubuh ikan. Berikut merupakan rumus perhitungan indeks kematangan gonad menurut Effendie (2002).

$$
\mathrm{IKG}=\frac{B g}{B t} \times 100 \%
$$

\section{Diameter Telur}

Sampel telur yang akan diamati diambil dengan kanulator \pm 20 butir lalu difiksasi dengan formalin $10 \%$ setelah itu kematangan telur diukur dengan mikroskop, kemudian dikonversi dengan faktor konversi dari pembesaran yang digunakan.

\section{Tingkat Kematangan Gonad}

Pengamatan tingkat kematangan gonad ikan baung dilakuakn secara morfologi dari hasil histologi gonad pada awal dan akhir penelitian. Histologi gonad dilakukan dengan menggunakan pewarnaan akhir hematoksilin dan eosin (H \& E). Uji histologi ini dilakukan di Balai Veteriner Lampung, Kota Bandar Lampung. Kemudian dilakukan pembacaan hasil histologi di Laboratorium Budidaya Perairan, Jurusan Perikanan dan Kelautan, Fakultas Pertanian, Universitas Lampung.

\section{Analisis Data}

Parameter diameter telur, Indeks Kematangan Gonad (IKG) dianalisis menggunakan analisis ragam (ANOVA). Apabila hasil uji antar perlakuan berbeda nyata maka akan dilakukan uji lanjut dengan uji Tukey, pada selang kepercayaan 95\% untuk mengkaji apakah terdapat pengaruh antar perlakuan. Parameter kualitas air, tingkat kematangan gonad secara morfologi dan histologi dan distribusi kematangan telur dianalisis secara deskriptif.

\section{Hasil dan Pembahasan}

\section{Indeks Kematangan Gonad (IKG)}

Hasil penelitian yang dilakukan pada akhir pengamatan bahwa pemberian hormon Oodev menunjukan hasil yang signifikan pada setiap perlakuan dan memberikan pengaruh yang berbeda nyata terhadap indeks kematangan gonad ikan baung $(\mathrm{P}<0,05)$.

Pada perlakuan $\mathrm{B}$, dan $\mathrm{C}$ tidak berbeda nyata dengan masing-masing dosis $0,25 \mathrm{ml} / \mathrm{kg}$ dan $0,5 \mathrm{ml} / \mathrm{kg}$, hal ini disebabkan karena pemberian dosis memicu peningkatan stadia atau ukuran oosit yang memberi dampak terhadap peningkatan gonadotropin dengan secara tidak langsung memproduksi estrogen yaitu estradiol-17 $\beta$ (Hartini \& Nurjannah, 2008) sehingga hormon Oodev yang mengandung PMSG mampu mempercepat kematangan gonad induk ikan baung.

Pada perlakuan B tidak berbeda nyata dengan perlakuan A dan D disebabkan pada saat sampling gonad yang ditemukan berkembang menjadi TKG III dimana terbentuknya ootid, dan diameter telur yang semakin besar sehingga nilai IKG pada perlakuan memiliki bobot gonad yang sama. Pada perlakuan A dan D tidak berbeda nyata meskipun dosis ditingkatkan. Hal ini disebabkan dosis yang diberikan dan waktu sampling 
yang tidak tepat sehingga gonad mengalami atresia. Atresia merupakan penyerapan kembali kuning telur yang tidak digunakan oleh folikel (Lubzens et al., 2010 dalam Rakhmawati, 2015). Hal ini terjadi karena dosis hormon Oodev yang tinggi mempercepat kematangan gonad, sehingga pada saat sampling telah ditemukaan gonad yang bobotnya telah menurun. Pemberian dosis yang berlebih dapat mengganggu keseimbangan jumlah hormon pada tubuh ikan, sehingga kelebihan hormon tersebut akan dikeluarkan melalui sistem sekresi (Mylonas et al., 2010).

Perlakuan C berbeda nyata dengan perlakuan A dan D dikarenakan PMSG yang mengandung FSH bekerja secara optimum pada induk ikan baung yang sedang mengalami perkembangan gonad tahap awal. Peningkatan nilai IKG disebabkan oleh proses vitelogenin. Selama proses vitelogenesis berlangsung maka granula kuning telur semakin bertambah jumlah dan ukuran sehingga volume oosit membesar, seiring adanya perkembangan oosit yang ditandai dengan semakin meningkatnya nilai IKG. Berdasakan pernyataan Effendie (2002) bahwasanya nilai IKG akan semakin meningkat nilainya dan akan mencapai nilai maksimum pada saat akan terjadi pemijahan. Nilai IKG yang naik setelah diinduksi hormon Oodev diduga bahwa hormon Oodev yang mengandung PMSG mampu mempercepat kematangan gonad induk ikan baung.

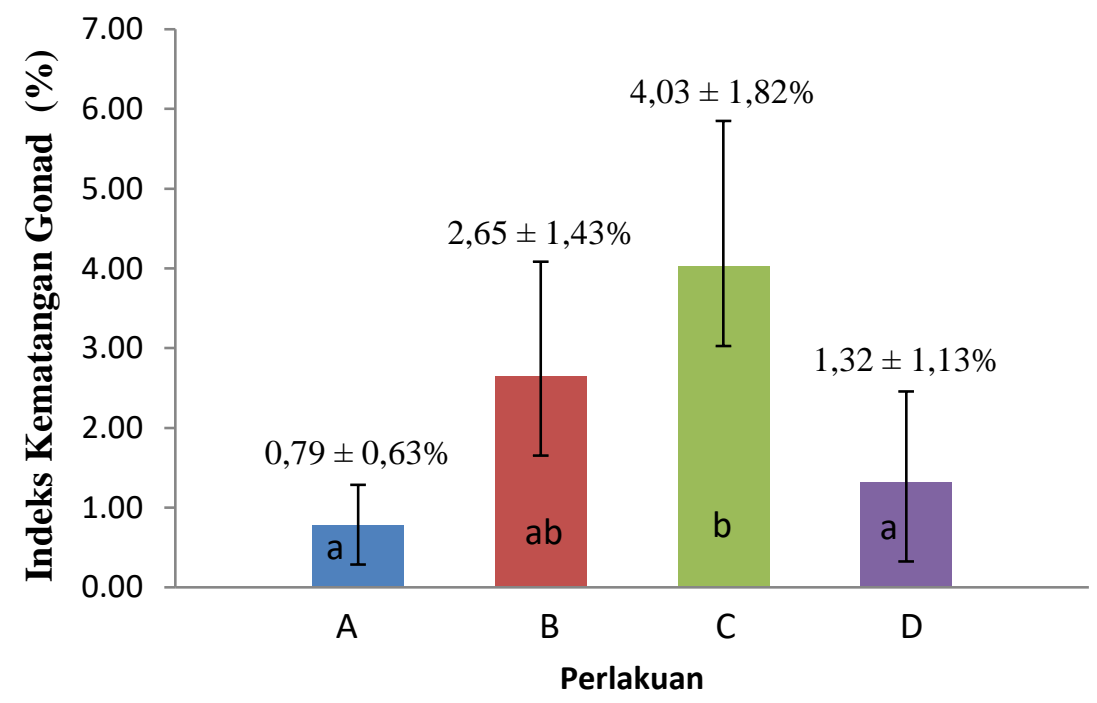

Gambar 1.Indeks kematangan gonad (\%) induk ikan baung betina.

\section{Diameter Telur}

Data hasil pengamatan diameter telur berdasarkan 20 sampel pada setiap perlakuan didapatkan nilai ratarata diameter telur. Hasil penelitian yang dilakukan pada akhir pengamatan bahwa pemberian hormon Oodev menunjukkan hasil yang berbeda nyata setiap perlakuan terhadap diameter telur ikan baung. 


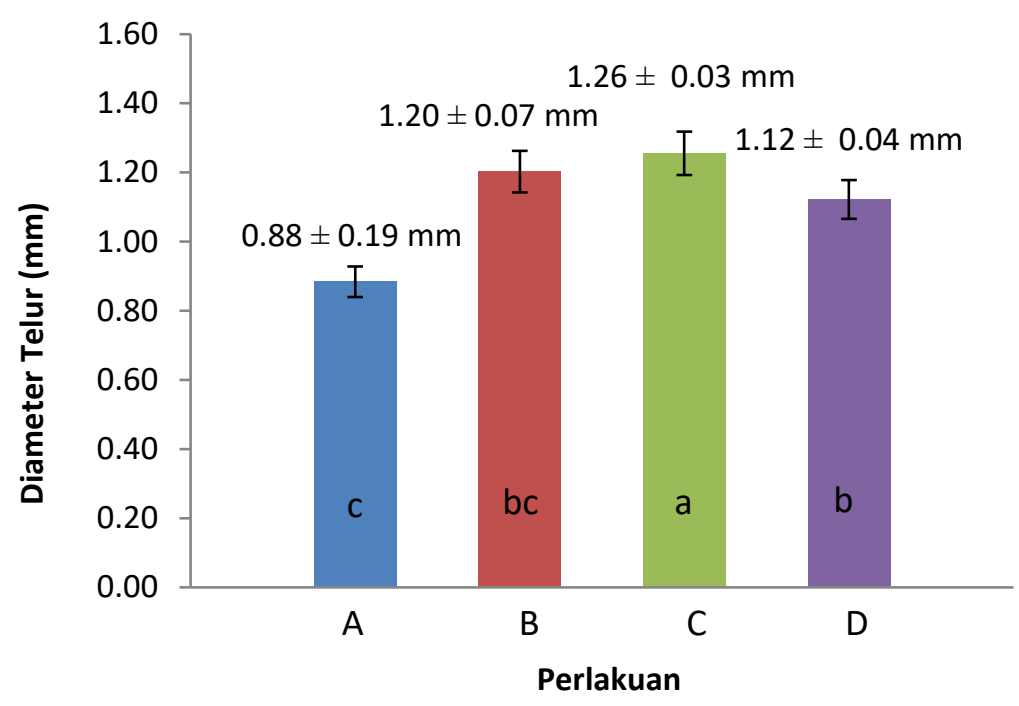

Gambar 2. Diameter telur induk betina ikan baung

Hasil penelitian yang dilakukan pada akhir pengamatan bahwa pemberian hormon Oodev memberikan pengaruh terhadap ukuran diameter telur ikan baung. Hasil pengukuran diameter telur ikan baung pada masing-masing perlakuan menunjukan adanya perkembangan rata-rata diameter dengan ukuran yang bervariasi. Pada perlakuan $\mathrm{C}$ berbeda nyata dengan perlakuan A, B, dan $\mathrm{D}$ sedangkan perlakuan $\mathrm{B}$ tidak berbeda nyata dengan perlakuan $\mathrm{A}$ dan D.

Pada perlakuan $\mathrm{C}$ yang berbeda nyata dengan seluruh perlakuan disebabkan bertambahnya perolehan ukuran rata-rata diameter telur menunjukan adanya perkembangan perkembangan oosit dalam gonad dan proses vitelogenesis yang menuju tahap maturasi. Diameter telur sangat berpengaruh terhadap jumlah kuning telur, yang merupakan sumber energi bagi embrio pada masa awal pertumbuhannya, ikan mampu menyerap maksimal sehingga mempercepat proses vitelogenesis.
Hormon yang bekerja dalam proses pematangan gonad ikan yaitu gonadotropin, dan pada hormon Oodev mengandung PMSG yang memiliki kandungan FSH yang lebih tinggi dibandingkan LH. PMSG merangsang terjadinya lonjakan kadar GnRH yang selanjutnya akan mempengaruhi pituitary untuk memproduksi gonadotropin. Setelah itu gonadotropin akan merangsang ovari untuk proses pematangan telur pada ikan. Hormon PMSG mampu merangsang pertumbuhan sel ovarium, pertumbuhan dan pematangan folikel, sehingga mampu meningkatkan diameter telur ikan dan menyebabkan kematangan telur terjadi.

Pada perlakuan B tidak berbeda nyata dengan perlakuan A disebabkan oleh proses vitelogenesis yang dicirikan dengan bertambahnya volume oosit yang berasal dari luar sel, yakni kuning telur, sehingga selama proses vitelogenenis berlangsung terjadi penambahan ketebalan dan diameter pada sel-sel 
granulosa, zona radiata dan sel teka (Nainggolan, 2014). Hal tersebut menunjukan bahwa semakin bertambahnya kematangan gonad, telur yang berada pada gonad semakin besar, begitu juga sebaliknya semakin rendah tingkat kematangan gonad maka diameter telur semakin kecil.

Pada perlakuan B tidak berbeda nyata dengan perlakuan $D$ hal ini disebabkan oleh dosis yang ditingkatkan yakni sebesar $1 \mathrm{ml} / \mathrm{kg}$ mempercepat kematangan gonad dan waktu sampling yang tidak tepat menyebabkan gonad mengalami penyusutan sehingga diperoleh ukuran diameter telur yang menurun, hal ini disebut atresia yang ditandai dengan gonad yang telah mengempis karena kuning telur yang digunakan untuk perkembangan embrio diserap kembali oleh folikel. Atresia merupakan proses degeneratif dari folikel-folikel ovari yang hilang atau penyerapan oosit vitelogenik sesaat sebelum ovulasi dan proses ini mengakibatkan penurunan potensi reproduksi pada ikan (Santos et al., 2008).

\section{Histologi Gonad}

Pada akhir penelitian dilakukan uji histologi pada gonad induk ikan baung. Dari hasil hstologi didapatkan bahwa perlakuan $\mathrm{C}$ mengalami perkembangan sampai ke TKG IV (mature oocyte) sedangkan perlakuan A, B, dan D masih berada pada TKG III (maturing oocyte). Secara umum gonad yang diberi perlakuan hormon Oodev mengalami pematangan gonad (Gambar 4).

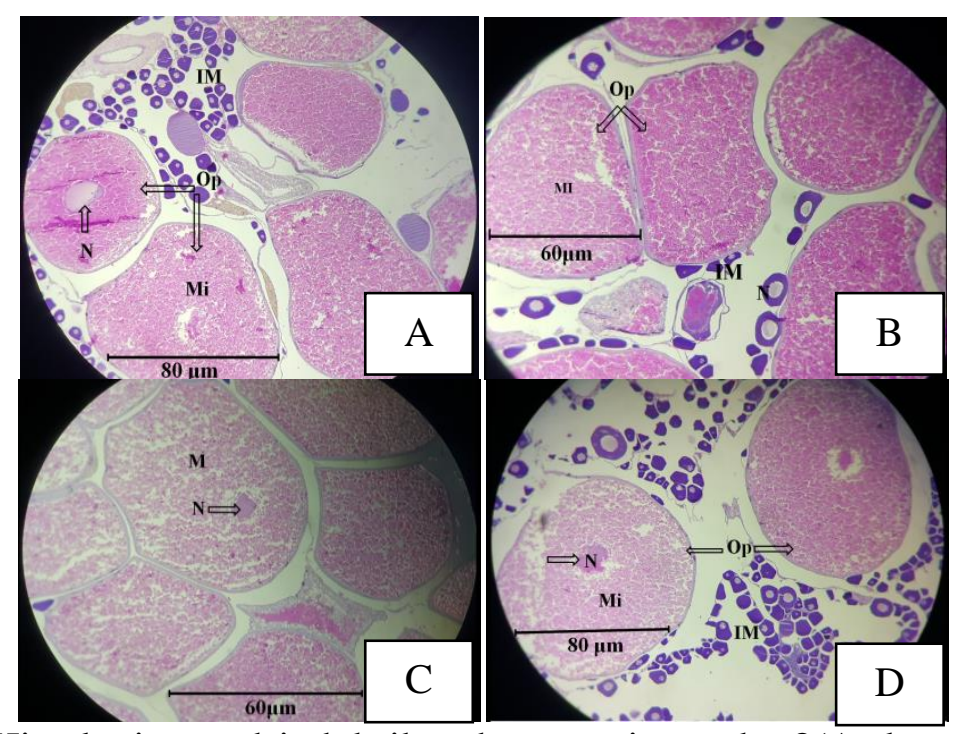

Gambar 3. Histologi gonad induk ikan baung minggu ke-8( yaitu $\mathrm{NaCl} 1,0 \mathrm{ml} / \mathrm{kg}$ ikan, B: hormon Oodev dosis $0,25 \mathrm{ml} / \mathrm{kg}$ + larutan fisiologis $0,75 \mathrm{ml} / \mathrm{kg}$ ikan, $\mathrm{C}$ : hormon Oodev dosis $0,5 \mathrm{ml} / \mathrm{kg}$ + larutan fisiologis $0,5 \mathrm{ml} / \mathrm{kg}$ ikan, D: hormon Oodev dengan dosis $1,0 \mathrm{ml} / \mathrm{kg}$ ikan)

Pada minggu ke-8, setelah diberi perlakuan dengan pemberian hormon Oodev perkembangan tingkat kematangan gonad terus mengalami peningkatan. Pada perlakuan A, B, dan perlakuan $\mathrm{D}$, hasil pengamatan 
secara morfologi gonad berada pada TKG III memiliki ciri-ciri butiran telur sudah terlihat jelas dengan warna gonad kuning merah muda dan ukuran ovarium relatif besar dan mengisi $1 / 3$ dari rongga tubuh. Pada hasil histologi menunjukkan bahwa perlakuan $\mathrm{A}, \mathrm{B}$, dan perlakuan $\mathrm{D}$ sebagian besar oosit mulai berkembang menjadi ootid (Oosit primer), inti sel bertambah besar tapi masih berada di tengah.

Pada TKG III terlihat bahwa kantong kuning telur mulai terbentuk, proses ini dikarenakan pembesaran oosit terutama disebabkan oleh penimbunan kuning telur. Penimbunan kuning telur oleh oosit ini disebut dengan proses vitellogenesis. Menurut Hutagalung et al. (2015), pada proses vitellogenesis ini, oosit akan menyerap kandungan vitellogenin, sehingga memperbesar volume oosit seiring dengan perkembangan gonad.

Pada perlakuan C secara morfologi, gonad memiliki ciri-ciri bentuk ovari yang memenuhi rongga tubuh, mengakibatkan usus terdesak, dengan butir telur yang berwarna kuning terlihat dengan jelas dan terlihat pada bagian perut yang membengkak terutama pada bagian urogenital dengan lubang urogenital yang berwarna agak kemerahan. Hasil uji histologi menunjukkan bahwa secara keseluruhan telah masuk ketahap mature, dan ditandai dengan oosit yang sudah tua degan berakhirnya masa pembentukkan kuning telur dan sebagian besar oogonium telah berkembang menjadi oosit primer.

Pada perkembangan tingkat kematangan gonad secara kualitatif dengan mengamati morfologi dan histologi gonad ikan baung dapat dilihat pada Tabel 1.

Tabel 1. Tingkat Kematangan Gonad Ikan Baung (Hemibagrus nemurus)

\begin{tabular}{ccc}
\hline $\begin{array}{c}\text { Hormon } \\
\text { Oodev }\end{array}$ & $\begin{array}{c}\text { Tingkat Kematangan } \\
\text { Gonad }\end{array}$ \\
\hline Perlakuan & H0 & H56 \\
\hline A & I & III \\
B & I & III \\
C & I & IV \\
D & I & III \\
\hline
\end{tabular}

Tabel 2. Distribusi kematangan gonad

\begin{tabular}{|c|c|c|c|}
\hline \multirow[t]{2}{*}{ Perlakuan } & \multicolumn{3}{|c|}{$\begin{array}{c}\text { Tahap Kematangan } \\
\text { Gonad }\end{array}$} \\
\hline & Pra & Vit & Mat \\
\hline $\mathrm{A}$ & $80 \%$ & $8 \%$ & $12 \%$ \\
\hline B & $50 \%$ & $30 \%$ & $20 \%$ \\
\hline $\mathrm{C}$ & $30 \%$ & $27 \%$ & $43 \%$ \\
\hline $\mathrm{D}$ & $72 \%$ & $13 \%$ & $15 \%$ \\
\hline
\end{tabular}

Distribusi kematangan gonad pada TKG III masih didominasi oleh pravitelogenin, pada fase ini bersamaan dengan berkembangnya oosit yang tumbuh di dalam nukleus dengan jumlah yang berbeda pada setiap masing-masing oosit. Pada tahap ini terlihat beberapa pembentukan butiran kuning telur dan lemak disekeliling nukleus yang menyebabkan perkembangan sitoplasma.

Pada tahap ini nukleus masih berada pada posisi inti. Memasuki tahap vitelogenesis, nukleus akan bermigrasi ke pinggiran oosit dan terjadinya pertambahan ukuran seta jumlah butiran kuning telur dan lemak mengisi sitoplasma, tahap ini disebut tahap awal vitelogenesis (early vitellogenesis).

Selanjutnya pada tahap akhir vitelogenesis (late vitellogenesis) terjadi pengendapan butiran kuning telur pada sisi tepi oosit yang matang 
dan kemudian menyebar ke seluruh sitoplasma mendekati nukleus. Proses ini mengakibatkan ukuran nukleus semakin mengecil dan tidak beraturan. Butiran kuning telur mulai mengalami peleburan sejalan dengan berkembangnya sitoplasma. Memasuki tahap matang (mature) nukleus mulai keluar dari sitoplasma, dan butiran kuning telur mengalami peleburan (Arianti et al., 2017)

\section{Parameter Kualitas Air}

Hasil pengukuran kualitas air selama penelitian menunjukkan bats yang wajar untuk kehidupan induk ikan baung. Kisaran kualitas air dapat dilihat pada Tabel 3.

Tabel 3. Kualitas Air pemeliharaan induk ikan baung (Hemibagrus nemurus)

\begin{tabular}{ccc}
\hline Parameter & Kisaran & Nilai Optimum \\
\hline Suhu $\left({ }^{\circ} \mathrm{C}\right)$ & $27-28$ & $27-33^{*}$ \\
$\mathrm{pH}$ & $6-7$ & $5-9^{* *}$ \\
\hline
\end{tabular}

Keterangan: *Tang (2000)

** Putra et al. (2013)

Pengukuran suhu pada masa pemeliharaan berkisar $27-28{ }^{\circ} \mathrm{C}$, sedangkan untuk pengukuran $\mathrm{pH}$ berkisar $6-7$. Kisaran suhu ini masih bisa ditoleransi untuk perkembang biakan dan menunjang perkembangan dan kematangan gonad ikan baung. Menurut Tang (2000) suhu air optimal bagi pembenihan ikan baung berkisar antara $27-33^{\circ} \mathrm{C}$, sedangkan kisaran $\mathrm{pH}$ yang optimal bagi pemeliharaan ikan baung yakni $5-9$ (Putra et al., 2013).

\section{Kesimpulan dan Saran}

\section{Kesimpulan}

Kesimpulan yang diperoleh dari penelitian ini adalah :

1. Penyuntikan menggunakan hormon Oodev berpengaruh terhadap perkembangan kematangan gonad ikan baung (Hemibagrus nemurus).

2. Dosis yang optimum digunakan untuk kematangan gonad ikan baung adalah D yakni $1 \mathrm{ml} / \mathrm{kg}$ dengan interval waktu 2 minggu sekali dengan tingkat kematangan gonad IV.

\section{Saran}

Dosis yang disarankan untuk digunakan sebagai rangsangan perkembangan gonad ikan baung adalah $1 \mathrm{ml} / \mathrm{kg}$ berdasarkan indeks kematangan gonad dan tingkat kematangan gonad IV setelah diinduksi hormon Oodev.

\section{Daftar Pustaka}

Ahlina, H. 2015. Induksi gonad ikan sidat (Angulia bicolor bicolor) secara hormonal dengan menggunakan PMSG, AD, dan rGH. Tesis. Institut Pertanian Bogor, Bogor. 56 hlm.

Amornsakun, A. \& Hassan, A. 1997. Some Aspect in Early Life Stages in Larval Green Catfish (Mystus nemurus). Indon. Fish. Res. J.J., 3: $64-70$.

Amri, K. 2008. Ikan Baung. Gramedia Pustaka Utama, Jakarta. $88 \mathrm{hlm}$.

Amri, K. \& Khairuman. 2008. Buku Pintar Budidaya 15 Ikan Konsumsi. Agro Media Pustaka, Jakarta. 66 hlm. 
Arukwe, A. \& Goksoyr, A. 2003. Eggshell and egg yolk protein in fish, Hepatic protein for the next generation: Oogenetic, Population, and Evolutionary impications of endocrin discruption. Comparative Hepatology, 2(4): 1 - 20.

Arianti, D.N., Rahardjo, M.F., \& Zahid, A. 2017. Perkembangan sel telur ikan seriding Ambasis nalua (Hamilton, 1822). Jurnal Ikhtiologi Indonesia, 17(1): 115 123.

Bernier, J.N., Kraak, G.V.D., Farerell, A.P., \& Brauner, C.J. 2009. Fish endocrinology. Elsevier Academic Press, Amsterdam. 560 hlm.

Cholik, F., Poernomo, R.P., \& Jauzi, A. 2005. Akuakultur. Masyarakat Perikanan Nusantara dan Taman Akuarium Air Tawar-TMII, Jakarta. 415 hlm.

Ediwarman. 2010. Pengaruh tepung ikan lokal dalam ikan induk terhadap pematangan gonad dan kualitas telur ikan baung (Hemibagrus nemurus Blkr). Skripsi. Fakultas Ilmu Perikanan dan Kelautan, Institut Pertanian Bogor, Bogor. 98 hlm.

Effendie, M.I. 2002. Biologi Perikanan. Yayasan Pustaka Nusantama, Yogyakarta. $163 \mathrm{hlm}$.

Elliot, J.M. \& Hurley, M.A. 1995. Functional Ecology. British Ecological Society, British. 343 hlm.

Farastuti, E.R. 2014. Induksi maturasi gonad, ovulasi dan pemijahan pada ikan torsoro (Tor soro) menggunakan kombinasi hormon. Tesis. Institut Pertanian Bogor, Bogor. 35 hlm.

Fithra, R.Y. \& Siregar, Y.I. 2010. Keanekaragaman ikan Sungai
Kampar Inventarisasi dan Sungai Kampar Kanan. Jurnal Ilmu Lingkungan, 2(4): 139 - 147.

Jalabert, B. 2005. Particularities of reproduction and oogenesis in teleost fish compared to mamals. Reproduction Natural Development, 45(3): 261 - 279.

Kordi, K.M.G. 2010. Budidaya Ikan Tambakan di Kolam Terpal. Lily Publisher, Yogyakarta.

Kuo, C.M., Nash, C.E., \& Watanabe, W.D. 1979. Induce breeding experiment with milkfish (Chanos chanos). Forskal, in Hawai. Aquaculture, 18(2): 95 - 105.

Lagler, K.F., Bardach, J.E., Miller, R.R., \& Passino, D.R.M. 1962. Ichthyology. John Wiley and Sons, Inc, Toronto. $545 \mathrm{hlm}$.

Lahnsteiner, F., Urbanyi, B., Horvarth, A., \& Weismann, T. 2001. Bio-markers for egg quality determination in cyprinid fish. Aquaculture, 195(3-4): 331 - 352.

Muflikhah, N., Nurdawati, S., \& Aida, S.N. 2005. Pengaruh pakan yang berbeda terhadap pematangan gonad ikan baung (Mystus numerus C.V.) dalam karamba, kualitas telur, dan sintasan larva. Jurnal Perikanan, 6(1): $1-10$.

Nagahama, Y. \& Yamashita, M. 2008. Regulation of Oocyte Maturation in Fish. Development, Growth and Differentiation, 50(1): $195-219$.

Nikolsky, G.V. 1963. The Ecology of Fishes. Academic Press, New York. $195 \mathrm{hlm}$.

Noga, E.J. 2010. Fish disease diagnosis and treatment. Blackwell Publishing, Iowa. 215 hlm. 
Rafiuddin, M.A. 2014. Kloning, karakterisasi dan rekayasa ekspresi gen FSH Follicle Stimulating Hormone subunit pada ikan patin siam (Pangasianodon hypophthalmus) untuk mempercepat maturasi gonad. Tesis. Institut Pertanian Bogor, Bogor. $54 \mathrm{hlm}$.

Rukmini. 2012. Teknologi Budidaya Biota Air. Karya Putra Darwati, Bandung. $228 \mathrm{hlm}$.

Saputra, W. 2008. Evaluasi tingkat eksploitasi sumberdaya ikan gulamah (Johnius sp) berdasarkan data TPI PPS Cilacap. Skripsi. Fakultas Perikanan dan Ilmu Kelautan Universitas Diponegoro, Semarang.

Sheima, I.A.P. 2011. Laju eksploitasi dan variasi temporal keragaman reproduksi ikan banban (Engraulis grayi) betina di pantai Utara Jawa pada bulan April - September. Skripsi. Fakultas Perikanan dan Ilmu Kelautan, Institut Pertanian Bogor, Bogor.

Sihaloho, O.I.S. 2014. Induksi pematangan gonad calon induk ikan patin siam (Pangasianodon hypophthalmus) ukuran $3 \mathrm{~kg}$ menggunakan Oodev melalui penyuntikan. Tesis. Institut Pertanian Bogor, Bogor.

Sukendi, 2001. Biologi reproduksi dan pengendaliannya dalam upaya pembenihan ikan baung (Mystus nemurus $C V$ ) di perairan Sungai Kampar, Riau. Disertasi. Institut Pertanian Bogor, Bogor. 270 hlm.

Susanto, H. 1999. Teknik Kawin Suntik Ikan Ekonomis. Penebar Swadaya, Jakarta.

Supyan. 2011. Aspek Biologi Ikan Baung. Jurnal Penelitian Perikanan, Jakarta.
Tang, U.M., Alawi, H., \& Putra, R.M. 1999. Pematangan gonad ikan baung (Mystus numerus) dengan pakan dan lingkungan yang berbeda. Hayati, 6: 10 - 12 .

Utiah, A., Zairin Jr., M., Mokoginta, I., Affandi, R., \& Sumantadinata, K. 2007. Kebutuhan asam lemak N-6 dan N-3 dalam pakan terhadap penampilan reproduksi induk ikan baung (Hemibagrus nemurus). Jurnal Akuakultur Indonesia, 6(1): $7-15$.

Wallace, R.A. \& Selman, K. 1981. Cellular and dynamic aspects of oocyte growth in teleosts. American Zoologist, 21(2): 325 343. 